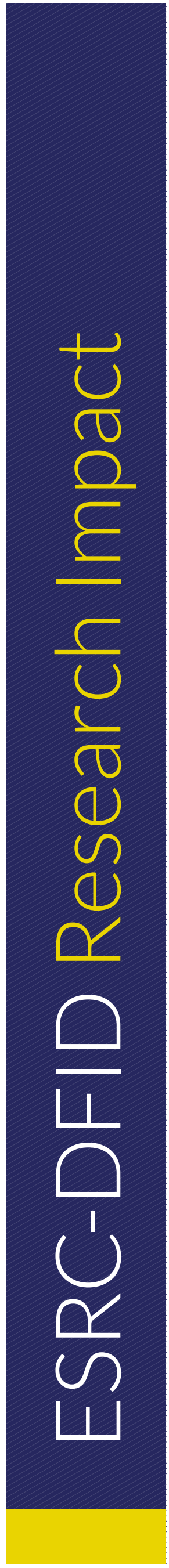

\title{
THE ROLE OF TEACHERS IN PEACE-BUILDING IN RWANDA AND SOUTH AFRICA
}

In 1994, both Rwanda and South Africa emerged from a long and protracted history of colonisation, conflict, genocide, and apartheid which left lasting scars on their education systems. Both countries have undertaken educational reforms to try to strengthen social cohesion. Research led by the University of Sussex in collaboration with the University of Rwanda and the Cape Peninsula University of Technology, Cape Town examined how education policy interventions have helped teachers to become active agents of peace-building. It found that more professional development, policy direction, and support are needed.

\section{THE CHALLENGE}

Education plays a vital role in rebuilding crisis-affected communities and preparing residents for a peaceful future. However, despite progress being made in both South Africa and Rwanda, significant challenges remain in rebuilding education systems that promote and create conditions in which teachers - many of whom were former victims and perpetrators of violence - can play a key role in nation-building, identity construction, and peace and reconciliation.

\section{THE RESEARCH}

Data collected from one-to-one interviews with education and peace-building stakeholders, focus groups, lesson observations, and analyses of statistical data and policy documents helped researchers understand the challenges and opportunities faced by teachers in post-conflict environments.
In both countries, findings showed an uneven

distribution of well-trained, quality teachers as well as a shortage of teachers able to teach effectively in the language of instruction. Trust between teachers and students was found to be low, making teachers less open to developing practices to promote peace and social cohesion. Furthermore, there was a general consensus among teachers that professional development provision failed to equip them with the knowledge and skills needed to tackle historical legacies that continue to fracture society along race, class, gender, and ethnic lines.

The research also highlighted how the two countries' national education policy directives took different approaches to guide how teachers might contribute to their respective policy visions of peace. In Rwanda, for example, the state has incorporated teachers into

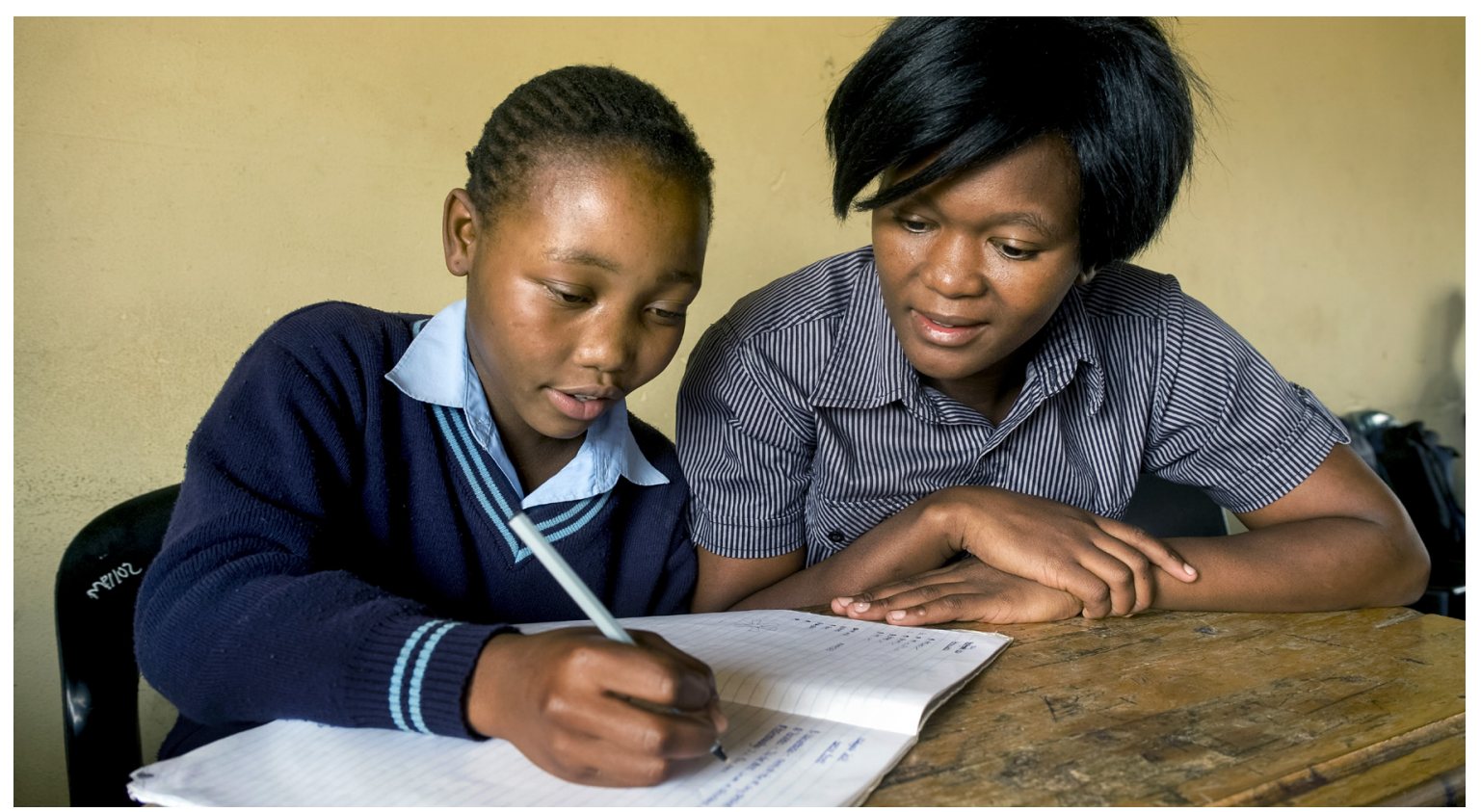

Cover photo: In a South African High School, a trainee teacher helps a pupil with her homework. Credit: Graeme Williams / Panos. 
the mission of eradicating ethnic differences with the objective of emphasising a collective 'Rwandanness'. In South Africa, teachers are expected to support the idea of a 'rainbow nation' embracing diversity.

Based on their findings, the researchers made the following policy recommendations:

Improve teacher distribution: Equitable distribution of teachers in post-conflict contexts involves getting the right teachers into both rural and urban locations, serving the most disadvantaged and those most impacted by historic conflict.

\section{Build trust in and accountability of teachers:}

Student-teacher trust and accountability are crucial for social cohesion initiatives. Teacher Councils such as South African Council for Educators (SACE) in South Africa and Rwanda Education Board (REB) in Rwanda, which are designed to promote teacher trust and accountability, require more support.

\section{Develop socially cohesive curricula and textbooks:}

A socially cohesive curriculum can help to lay the foundations for a democratic, open, and united society. Textbooks should be free from bias and discrimination, and should actively disrupt assumptions about identity markers such as race, ethnicity, gender, class, religion, region, and language.

\section{Support teachers to develop inclusive pedagogies:}

Teachers need to be provided with the psychosocial support and understanding to overcome their 'woundedness' as a result of the histories of conflict in both countries as well as engage with their own prejudices and biases when it comes to teaching, particularly in relation to genocide in Rwanda and apartheid in South Africa.

\section{THE IMPACT}

Several universities across South Africa are revamping their inclusive education programmes to better prepare teachers drawing on insights from the research. A teacher educator from the University of Cape Town said, 'We are looking at this research in terms of inserting key information and analysis into the various modules on teacher practice and teacherpupil engagement around conflict situations and the generation of greater solidarity.'

In addition, in South Africa, the project's Principal Investigator, Yusuf Sayed, was appointed as a member of the Department for Basic Education's Ministerial Task Team for the review of textbooks. This review focuses on issues of discrimination, equity, and social cohesion.

Workshops were also held to share findings with policymakers. As a result, in Rwanda, ministry officials have agreed to embark on the implementation of continuing professional development, focusing particularly on social cohesion and peace-building.

An ongoing dialogue between the research team and the South African Deputy Minister of Basic Education, Enver Surty, culminated in the Teachers and Social Cohesion Roundtable in 2016; and in 2017, on the 20year anniversary of the South African Constitution, $\mathrm{Mr}$ Surty assured that the work would inform future social cohesion developments in education. This was echoed by the Executive Director of the Institute for Justice and Reconciliation, Stanley Henkeman, who said:

'The research project has proved to be an invaluable contribution to the renewal and transformation of the South African education system. It deals with matters of inclusion and social cohesion in a holistic manner and provides useful insights for educators.'

\section{FURTHER READING}

Sayed, Y. et al. (2018) The Role of Teachers in Peacebuilding and Social Cohesion in Rwanda and South Africa: Synthesis Report, ESRC-DFID Research Report, Brighton: University of Sussex, http://s3.amazonaws. com/inee-assets/resources/15-Role-of-teachers-inpeacebuilding-synthesis-report-final.pdf

Ndabaga, E. et al. (2017) Engaging Teachers in Peacebuilding in Post-Conflict Context: Evaluating Education Interventions in Rwanda, ESRC-DFID Research Report, Brighton: University of Sussex, https://www.sussex.ac.uk/webteam/gateway/file. php?name=evaluating-education-interventions-inrwanda-final-report.pdf\&site $=320$

Sayed, Y . et al. (2017) Engaging Teachers in Peacebuilding in Post-Conflict Context: Evaluating Education Interventions in Rwanda, ESRC-DFID Research Report, Brighton: University of Sussex; https://www.sussex. ac.uk/webteam/gateway/file.php?name=evaluatingeducation-interventions-in-south-africa-finalreport-v1.pdf\&site $=320$

Sayed, Y. (2016) 'Teachers Have a Crucial Role to Play in Building Social Cohesion', The Conversation, 29 August

Sayed, Y. (2016) 'Pupils Deserve Applause for Demanding a Just School System. The Conversation, 1 September

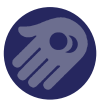

Engaging Teachers in Peace-building in Post-Conflict Contexts: Evaluating Education Interventions in Rwanda and South Africa

The research team was funded by the ESRC-DFID Joint Fund for Poverty Alleviation Research, led by Yusuf Sayed, Professor of International Education and Development Policy, University of Sussex, UK. The research is a collaborative project involving the University of Bristol, UK; the Centre for International Teacher Education (CITE) at the Cape Peninsula University of Technology, South Africa; and the College of Education, University of Rwanda.

\section{THE IMPACT INITIATIVE}

\section{For International Development Research}

The Impact Initiative seeks to connect policymakers and practitioners with the world-class social science research supported by the ESRC-DFID Strategic Partnership, maximising the uptake and impact of research from: (i) the Joint Fund for Poverty Alleviation Research, and (ii) the Raising Learning Outcomes in Education Systems Programme. We seek to identify synergies between these programmes and their grant holders, support them to exploit influencing and engagement opportunities, and facilitate mutual learning. The Impact Initiative is a collaboration between the Institute of Development Studies (IDS) and the University of Cambridge's Research for Equitable Access and Learning (REAL) Centre.

All content is available under the Open Government License v3.0, except where otherwise stated.

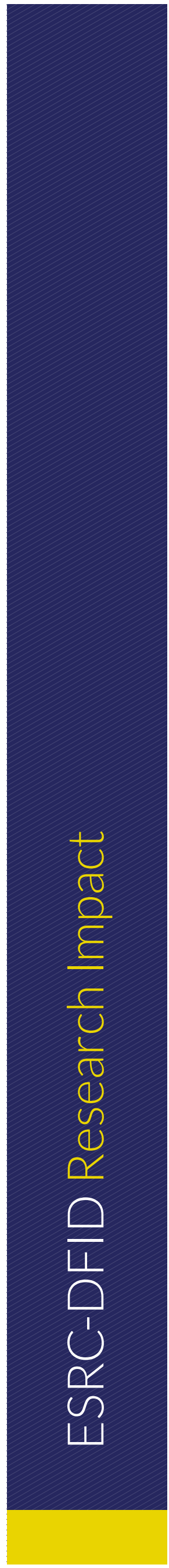

